\title{
Um império de galinhas e baratas
}

C) ARRANCAS, pertencente à vila de São João d'el Rei, foi palco de uma insurreição escrava no dia 13 de maio de 1833. Filhos, netos, sobrinhos, noras, genros e agregados do deputado Gabriel Junqueira foram mortos por seus escravos, aparentemente instigados pelo rumor de que em outras localidades se fazia o mesmo. Ao final dos conflitos armados e prisão dos insurgentes, foram julgados 33 escravos, sendo a maioria condenada à morte. Os julgamentos se deram pelo Código Criminal do Império, aprovado no ano anterior: era considerado crime de insurreição a reunião de mais de vinte escravos dispostos a conseguirem sua liberdade por meio da força. Aos cabeças poderia ser imposta a pena de morte em grau máximo, e aos demais participantes, açoites. Os réus poderiam ainda apelar a um segundo júri ou à Relação, apesar de não poderem apelar ao monarca. Na prática, a maioria dos insurgentes foi executada sem que o curador dos réus tivesse apelado, talvez por julgar inconveniente diante da opinião pública. Os últimos enforcamentos ocorreram em 1834.

No mesmo ano de 1833, no mês seguinte ao ocorrido em Carrancas, o Ministério da Justiça da Regência Trina Permanente enviava ao Parlamento uma proposta de lei que reprimisse os levantes escravos. Não se tratava de simples haitianismo, um receio de que o Brasil fosse palco de conflito idêntico aos ocorrido no Haiti no século anterior. O episódio de Carrancas não havia sido o primeiro e também não seria o último em que escravos se levantariam contra seus senhores. Junto ao projeto original foram enca- minhados outros três, propondo alterações na Guarda Nacional, no Corpo de Permanentes e regulando a liberdade de imprensa. O período era de certa intranqüilidade, inúmeros conflitos contestatórios surgiam em diversos pontos do Império, alguns mais sérios, outros mais pontuais. Simultaneamente à insurreição de Carrancas e na mesma região ocorrera a Revolta do Ano da Fumaça, mais uma entre várias tentativas de promover o retorno de D. Pedro I. Os quatro projetos de lei tinham em comum o caráter repressivo, cada qual a seu modo, pois se entendia que era necessária maior coerção a fim de se garantir a coesão da Nação, controlando os adversários políticos, os homens livres pobres, os periódicos ou os negros escravos.

O projeto de lei a respeito dos crimes cometidos por escravos apresentado pela Regência foi acolhido pela Câmara com pequenas alterações, apesar dos debates. Em poucas palavras, propunha a aceleração dos processos contra escravos acusados de assassinar ou ferir gravemente seus senhores, feitores, administradores, ou os familiares desses: acabavam-se as apelações e as gradações de penas; essas estariam limitadas a apenas duas, a morte pela forca ou açoites em caso de ferimentos leves. Uma lei de exceção para uma época excepcional. Ou para uma sociedade excepcional?

São exatamente as relações entre uma lei, sua prática e a sociedade que as engendra que constitui o objeto do extenso e profundo estudo realizado por João Luiz Ribeiro em seu livro No meio das galinhas as baratas não têm razão. De fato, diante do tema os debates parlamentares já se- 
riam suficientes para a elaboração de uma dissertação de mestrado de significativa importância. No entanto, essa dissertação defendida na UFRJ, em 2000, vai além. $\mathrm{O}$ autor mineiro preferiu não se ater somente à história política, explorando também a sociedade na qual se dá a ação política e sua organização por meio das leis. Um direito vivo transitando entre a legislação em si e sua aplicação, que não por poucas vezes se mostraram esferas distintas.

Desse modo, a Lei de 10 de junho de 1835 , citada no subtítulo do livro, representa apenas um fenômeno, a parte mais visível em um todo muito mais complexo. Para além da superfície do texto da legislação se encontram deputados, senadores, juízes, jurados, advogados, promotores, as vítimas e suas famílias, todos cidadãos e, por conseguinte, proprietários de escravos ou a eles relacionados. O debate ocorrido na Câmara, entre 1833 e 1835, e simultaneamente às discussões do Ato Adicional, mostra com clareza essa situação ímpar: viver em uma sociedade escravista era conviver com a tensão natural existente entre senhores e escravos. Cabia aos primeiros fazer que os últimos produzissem de forma satisfatória, bem como era dever dos representantes legais no Parlamento, garantir os meios sob os quais se dariam a produção e o controle da mão-de-obra. Assim se esperava de um Estado e de uma sociedade organizados de acordo com os preceitos liberais, os mesmos preceitos que nortearam a confecção da Carta de 1824 e dos Códigos brasileiros.

No caso das regras do jogo político estabeleceram-se a representatividade por meio do processo eleitoral e a instituição de uma arena política claramente definida, um parlamento bicameral. Quanto à aplicação das leis, Ribeiro menciona que os legisladores brasileiros seguiam as idéias mais "avançadas" (e também as mais polêmicas) à época, entre elas o julgamento por jurados. Ao contrário do sistema judiciário dos tempos coloniais, a legislação do Império partia de premissas oriundas do pensamento iluminista. Todo cidadão seria igual perante a lei, respondendo a punições na proporção da infração cometida, de acordo com o julgamento realizado por seus pares, os jurados. Esse sistema, entretanto, não era consensualmente aceito por nenhuma das nações que o adotou, assim como a pena de morte. A chamada "pena última" ou "capital", segundo o autor, gozava de uma aceitação de ocasião, um mal necessário diante de massas "bárbaras carentes" de sentimento de ordem. Esse argumento, facilmente imaginável na boca de um deputado brasileiro, fora originalmente utilizado por ingleses e franceses com o intuito de justificar a aplicação de pena tão extrema em países tão civilizados.

João Luiz Ribeiro, muito perspicaz, estabelece não apenas o debate diante das necessidades nacionais, mas também a reutilização de discursos semelhantes em casos aparentemente diferentes. Segundo o autor, o uso de "medidas extremas" na Inglaterra era justificado diante da necessidade de organizar os contingentes populacionais ainda não conscientes de seu papel na nova lógica do trabalho em fins do século XVIII e início do seguinte. Mostrava-se necessário aos olhos dos grupos dirigentes civilizar a população, ou seja, torná-la cidadã segundo um critério produtivo, ao mesmo tempo que se fazia urgente contê-la diante dos crescentes índices de criminalidade por meio de punições severas e exemplares. Algo semelhante ocorria no Brasil: não só era necessário punir os escravos assassinos de seus senhores para que a prática não se tornasse usual, 
como também se pretendia evitar uma possível desorganização da produção.

Desse modo, o trabalho de Ribeiro inscreve-se em debate mais amplo, pois refere-se às mediações entre liberalismo e escravidão, tema que tem sido alvo das reflexões de autores como Maria Silvia de Carvalho Franco, Emilia Viotti da Costa, Alfredo Bosi, João José Reis, José Murilo de Carvalho, Izabel Andrade Marson, entre outros. Apesar de não ir a fundo nessa questão, o autor oferece subsídios que indicam que as idéias liberais no Império do Brasil esbarravam em contradições únicas, mas soluções de modo igualmente peculiar eram encontradas. A igualdade entre cidadãos, por exemplo, era possível e existia, contanto que se estabelecesse claramente uma diferença entre os cidadãos e os "outros", de modo que cada um desses elementos que compunham a sociedade respondesse de forma diferente perante a lei.

Em uma sociedade escravista a divisão básica não poderia ser outra que não o senhor e o escravo; no entanto, a relação entre as partes está longe de ser simples. Ambas as partes encontravam-se dentro do Estado e, apesar da aparência, esse não estava sempre em harmonia com os cidadãos-proprietários, afinal dividiam o poder de coerção sobre setores da população. Cabia ao cidadão dispor sobre sua propriedade, direito inalienável, mas quando necessário exigia que o Estado, do qual fazia parte por meio de representantes eleitos, tomasse as providências cabíveis. Essa trama de interesses diversos articulados diante de demandas mútuas tornava a prática legal e mesmo o debate político muito mais complexos.

No caso da pena de morte aplicada aos escravos que assassinavam seus senhores ou feitores, fica patente a intromissão do Estado na propriedade privada de acordo com o interesse dos próprios proprietários que, no momento da aprovação da lei, já não viam outra saída diante da aparente ineficiência do açoite aplicado rotineiramente. $\mathrm{Na}$ verdade, a pena de morte em países como França e Inglaterra vinha sendo considerada pouco eficaz na contenção da criminalidade quando foi adotada no Brasil, e nesse sentido foi atacada por deputados nos debates de 1833 e 1834. No entanto, a Revolta dos Malês em Salvador, no ano de 1835, acabou por precipitar a assinatura da "lei de exceção", como ficou conhecida desde então por estar fora do direito comum. Conforme mostra Ribeiro, esperava-se que o medo da forca fizesse o escravo refrear o desejo de matar seu senhor. Do mesmo modo que a própria escravidão havia sido outrora considerada, a pena de morte passava a ser encarada também como um mal necessário ou um "terror salutar".

De acordo com a extensa pesquisa realizada por Ribeiro nos códices e correspondências do Judiciário, periódicos da Corte e de Províncias, e documentação gerada pelo Conselho de Estado, a pena capital aplicada a escravos atravessou fases diversas, sinalizando diferentes entendimentos a respeito da necessidade de uma lei tão severa, sem que nunca se discutisse sua supressão. A Lei de 10 de junho de 1835 deixou de existir, de fato, apenas com a Abolição da Escravidão, em 1888. No entanto, a letra interpretada por juízes, advogados, promotores e mesmo pelos conselheiros de Estado e pelo imperador variou muito ao longo desses 53 anos. Após a aprovação da lei até a maioridade do monarca, em 1840, o cadafalso viveu anos de destaque, o espetáculo da forca foi freqüente tanto na capital do Império quanto nas localidades mais remotas, na exata 
medida do que se entendia como uma resposta aos medos da sociedade escravista.

Essa situação se manteve quase inalterada, apesar de uma sutil diminuição no ritmo das execuções, até o início da década de 1850, quando mudanças significativas advindas com a Conciliação modificaram esse quadro. Segundo o autor, tanto o Gabinete Ministerial quanto o Conselho de Estado, seguindo uma posição pessoal do monarca, passaram, a partir de 1853, a agir de modo a flexibilizar a lei de 1835 sem, contudo, alterá-la.

Apesar de a legislação definir que a única apelação possível ao escravo condenado pela "lei de exceção" era ao Poder Moderador, desde que o recurso fosse impetrado por seu curador ou advogado de defesa, com o passar dos anos o apelo à imperial clemência se tornou regra. $\mathrm{Cu}^{-}$ riosamente, essa brecha foi sendo aberta por meio de orientações dadas pelos ministros da pasta da Justiça aos presidentes de Província e aos magistrados, sem que houvesse uma legislação nesse sentido aprovada pelo Poder Legislativo. No entanto, como mostra Ribeiro, seria ingenuidade supor que essa nova prática fosse fruto de um consensual humanitarismo que tomava conta dos corações de ministros e conselheiros.

Por mais que alguns, como o próprio D. Pedro II, se manifestassem claramente contra a pena última, outros tantos consideravam necessário corrigir apenas as injustiças cometidas pelos jurados ou juízes, fosse na formação da culpa fosse na sentença contra os escravos. O modo encontrado foi a comutação quase que sistemática da pena de morte em galés perpétuas, em especial a partir da década de 1860, período em que o Conselho de Estado passou a discutir projetos de emancipação do elemento servil. Por mais irônico que possa parecer, o escravo era salvo de morrer na forca para trabalhar pelo resto da sua vida sob o jugo do Estado, permanecendo em situação semelhante àquela anterior ao crime.

Se as mais altas esferas do poder chegaram ao ponto de interferir claramente nas decisões de julgamentos legítimos, algum motivo plausível haveria de existir. Não se pode deixar de ressaltar mais uma vez que o sistema de jurados significa o julgamento pelos pares. Entretanto, quando o réu é um escravo seus juízes de fato nunca serão seus iguais, e sim homens muito mais identificados à vítima, um senhor ou feitor. De tal sorte que todo tipo de artifício necessário à condenação do escravo poderia ser utilizado: aceitar uma testemunha "de ouvir dizer" como prova contundente, negligenciar o uso do Código Penal que proibia a condenação à morte quando a única prova era a confissão, entre outros.

Ribeiro toca ainda em uma questão muito importante quanto às dificuldades de se estabelecer a "verdade" em um julgamento do século XIX. Sem provas ditas científicas, toda a reflexão se dava com base em indícios, elementos capazes de criar um encadeamento lógico a fim de elucidar o caso. Do mesmo modo como uma roupa suja de sangue era indicativa de crime, a própria condição escrava era entendida como indício, na maioria das vezes promovida a evidência ou prova. No caso de escravos domésticos e crimes cometidos sem nenhuma testemunha, não haveria outras provas que não a própria confissão do réu e o fato de ser escravo.

Por vezes, havia a discordância entre o júri - os juízes de fato - e o juiz de direito, provocando a apelação desse às ins- 
tâncias superiores. Por mais que o magistrado pudesse fazer parte do mesmo grupo social que os jurados, mantinha-se em alguns casos uma diferença entre homens da sociedade em geral e homens da máquina do Estado, ligados ao rigor das leis. Porém, o Poder Moderador nunca perdoava sentenças, apenas as comutava, por mais que parecessem injustas. Situação que levava muitos juizes a "manipularem" os julgamentos, estabelecendo quesitos atenuantes, gerando uma jurisprudência que, a priori, estava vedada à Lei de 10 de junho de 1835.

É exatamente essa queda-de-braço constante entre jurados, juízes e Estado que anteriormente foi nomeado como um direito vivo capaz de conceder substância à letra da lei, aos códigos aprovados como tentativas de regulação de uma sociedade dinâmica. Em todo caso, os três componentes em embate cotidiano permanecem ligados entre si pela qualidade de cidadão, dependendo deles qualquer ação efetiva. Não à toa, quando se viu enredado nas inquirições e demais práticas forenses, o réu José Crioulo acabou por responder ao juiz, apesar de ter sido instado a calar-se: "V. Ex. bem sabe, no meio das galinhas, as baratas não têm razão". Utilizando as palavras de José Crioulo, não era mistério às baratas o modo de agir das galinhas.

Além da detalhada pesquisa documental, com sua copiosa coleta de processos, sentenças e debates, João Luiz Ribeiro oferece uma contribuição significativa a diferentes segmentos da pesquisa histórica. Os assassinatos de senhores e feitores por escravos contabilizados e analisados à luz da legislação reforçam as interpretações a respeito da resistência escrava e sinalizam uma "resistência à resistência escrava" responsável pela geração de uma imagem que estigmatiza o negro até hoje, fazendo dele um elemento suspeito, potencialmente criminoso. O mal-estar gerado no interior do estado por uma "lei de exceção" problematiza, por sua vez, a questão dos debates acerca da emancipação do elemento servil. Enquanto, de modo mais amplo, a relação desses elementos em um universo sociopolítico e econômico vem estimular as reflexões quanto à aplicação ou não das idéias liberais no seio de uma sociedade escravista, deixando no ar a indagação: ainda é possível crer que as idéias estão, ou poderiam estar, fora do lugar? Questões essas que o autor não pôde aprofundar talvez pela natureza de seu trabalho, uma dissertação de mestrado. Mas espera-se que futuramente o faça, pois sua minúcia na leitura das fontes e o cuidado no cotejamento das informações e interpretações devem servir de estímulo a outra pesquisa. Espera-se apenas que ao editar um novo trabalho não seja prejudicado pela falta de revisão final como o foi agora, quando um belo texto acabou manchado por inúmeros erros de digitação.

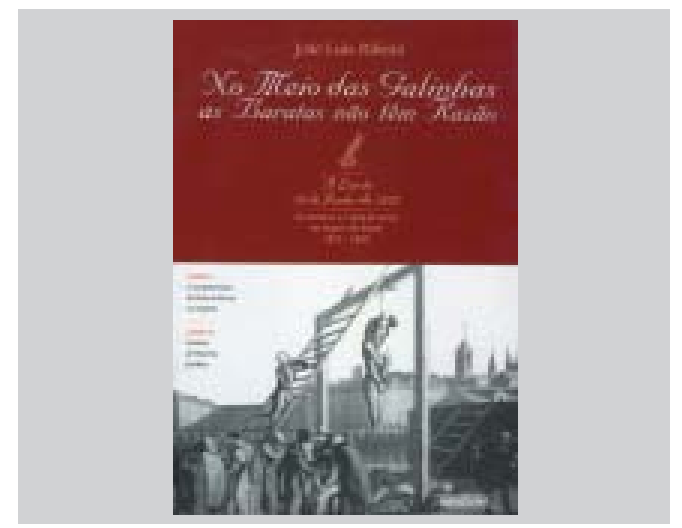

RIBEIRO, J. L. No meio das galinhas as baratas não têm razão. Rio de Janeiro: Renovar, 2005. 609p.

Erik Hörner é mestre em História Social pela FFLCH-USP e doutorando em História pela mesma instituição. 